progressive systemic sclerosis the liver is capable of producing acute phase proteins. In vitro studies of monocytes from patients with progressive systemic sclerosis have shown that when stimulated with lipopolysaccharide they are capable of producing interleukin $1 .{ }^{5}$ This suggests that infection, disease activity, and prostaglandin $E_{1}$ infusion have different mechanisms of producing an acute phase response, either at the level of macrophage stimulation or in the liver. Clearly further research is needed into the mechanisms of the acute phase response both in normal subjects and in patients with systemic lupus erythematosus and progressive systemic sclerosis.

\section{References}

1 Pepys MB. C reactive protein 50 years on. Lancet 1981 ;ii:653-7.

Amos RS, Constable TJ, Crockson RA, Crockson AP, McConkey B. Rheumatoid arthritis: relation of serum $C$ reactive protein and erythrocyte sedimentation rate. $B r$ Med f $1977 ;$ i: 195-7.

Becker G, Walderburger M Hughes GRV, Pepys MB. Value of CRP measurement in investigation of fever in SLE. Ann Rheum Dis 1980;39:50-2.

4 Whicher J, Bell A, Unwin J, Martin M, Dieppe P. The prostaglandin acute phase response is defective in endotoxin tolerant mice and humans with scleroderma. response is defective in endotoxin tolerant mice and humans with scleroderma. protein response to tissue injury. Ann NY Acad Sci 1982;389:482-5.

5 Sandborg CI, Berman M, Andrews B, Friou GJ. Interleukin 1 production by mononuclear cells from patients with scleroderma syndromes. Arthritis Rheum 1983;28 (suppl): 113 .

(Accepted 20 fuly 1984)

\title{
BamH I polymorphism in the Chinese: its potential usefulness in prenatal diagnosis of $\beta$ thalassaemia
}

\author{
VIVIAN CHAN, N K LEUNG, T K CHAN, A GHOSH, Y W KAN, D TODD
}

\begin{abstract}
The prevalence of the BamH I site $3^{\prime}$ to the $\beta$ globin gene in Chinese people was determined in 123 normal subjects, 40 patients with heterozygous $\beta$ thalassaemia, and 25 patients with homozygous $\beta$ thalassaemia. The site was present in $71.1 \%$ and absent in $28.9 \%$ of the chromosomes carrying normal $\beta$ genes. All 25 patients with $\beta$ thalassaemia major had the site.

This BamH I polymorphism may be used for prenatal diagnosis in about $29 \%$ of the pregnancies at risk.
\end{abstract}

\section{Introduction}

One approach in the prenatal diagnosis of $\beta$ thalassaemia is linkage analysis of the abnormal gene with polymorphic restriction sites on the chromosome. ${ }^{1}{ }^{2} \mathrm{Kan}$ et al observed that in Sardinians the $\beta$ thalassaemia gene is always located on the chromosome carrying the BamH I polymorphic site $3^{\prime}$ to the $\beta$ globin gene, ${ }^{1}$ and so absence of this site would exclude a diagnosis of homozygous $\beta$ thalassaemia. In the present study we compared, in Chinese subjects, the prevalence of BamH I polymorphism in the normal population with that in patients

University Department of Medicine, Queen Mary Hospital, Hong Kong

VIVIAN CHAN, PHD, DIC, reader

T K CHAN, MD, FRCP, professor

D TODD, MD, FRCP, professor

Paediatric Unit A, Princess Margaret Hospital, Kowloon, Hong Kong

N K LEUNG, MB, MRCP, consultant

University Department of Obstetrics, Queen Mary Hospital, Hong Kong

A GHOSH, MB, MRCOG, lecturer

Howard Hughes Medical Institute Laboratory, Department of Medicine, University of California School of Medicine, San Francisco, USA

Y W KAN, DSC, FRS, professor

Correspondence to: Dr V Chan. with $\beta$ thalassaemia. We also attempted prenatal diagnosis of homozygous $\beta$ thalassaemia using this polymorphism in a couple at risk.

\section{Subjects, methods, and results}

All subjects studied were Chinese. DNA was extracted from white cells obtained from 123 normal subjects, 25 patients with homozygous $\beta$ thalassaemia, and 40 patients with heterozygous $\beta$ thalassaemia. In addition, fetal DNA was prepared from uncultured amniotic fluid cells $(20 \mathrm{ml})$ obtained from a pregnant woman at risk for homozygous $\beta$ thalassaemia at 17 weeks' gestation. The BamH I digested DNA fragments were hybridised with phosphorus-32 $\left({ }^{32} \mathrm{P}\right)$ labelled $\beta$ globin probe as described previously ${ }^{1}$ and the specific fragments identified after autoradiography.

When human DNA was restricted with BamH I and hybridised to ${ }^{32} \mathrm{P}$ labelled $\beta$ globin probe the $1.8 \mathrm{~kb} 5^{\prime}$ and $9.3 \mathrm{~kb} \mathrm{3}$ fragments of the $\beta$ gene were visible. In subjects in whom the $3^{\prime}$ BamH I restriction site was abolished a longer $3^{\prime}$ fragment of $22 \mathrm{~kb}$ resulted. The table shows the distribution of the BamH I fragments containing the $3^{\prime} \beta$ globin gene. The prevalences of the $9 \cdot 3$ and $22 \mathrm{~kb}$ fragments in the 123

Distribution of BamH I fragments containing the $3^{\prime} \beta$ globin gene in Chinese subjects

\begin{tabular}{lrccccccc}
\hline & & \multicolumn{2}{c}{ BamH I pattern } & & \multicolumn{2}{c}{ Prevalence } \\
& $\mathrm{n}$ & & $9 \cdot 3 / 9 \cdot 3$ & $9 \cdot 3 / 22$ & $22 / 22$ & & $9 \cdot 3 \mathrm{~kb}$ & $22 \mathrm{~kb}$ \\
\hline Normal subjects & 123 & 61 & 53 & 9 & & $0 \cdot 711$ & $0 \cdot 289$ \\
Heterozygous $\beta$ thalassaemia & 40 & 30 & 10 & 0 & & $0 \cdot 875$ & $0 \cdot 125$ \\
Homozygous $\beta$ thalassaemia & 25 & 25 & 0 & 0 & & $1 \cdot 000$ & 0 \\
\hline
\end{tabular}

Chinese subjects without $\beta$ thalassaemia were 0.711 and 0.289 respectively. In subjects with heterozygous $\beta$ thalassaemia the corresponding prevalences were 0.875 and $0 \cdot 125$. In contrast, all patients with homozygous $\beta$ thalassaemia had the $9 \cdot 3 / 9 \cdot 3 \mathrm{~kb}$ pattern.

In the family presenting for prenatal diagnosis the father had one chromosome carrying the $9.3 \mathrm{~kb} \beta$ thalassaemia gene and one containing the $22 \mathrm{~kb}$ normal $\beta$ gene. In the mother both chromosomes carried the $9.3 \mathrm{~kb}$ fragments. The family contained two children with homozygous $\beta$ thalassaemia, both of whom exhibited a $9 \cdot 3 / 9 \cdot 3 \mathrm{~kb}$ pattern. When the fetal DNA was mapped a $9 \cdot 3 / 9 \cdot 3 \mathrm{~kb}$ pattern was observed. This indicated that the fetus was not normal but did not allow us to distinguish accurately between $\beta$ thalassaemia trait and homozygous $\beta$ thalassaemia. The mother refused globin chain analysis of fetal blood for additional diagnosis and elected to have an abortion. 
Blood collected from cardiac puncture of the aborted fetus showed no haemoglobin A on isoelectrofocusing and cellulose acetate electrophoresis. Haemoglobin $\mathrm{F}$ was the only detectable haemoglobin.

\section{Discussion}

Fetal blood sampling for globin chain synthesis has been the main method of diagnosing $\beta$ thalassaemia prenatally. It is performed in the midtrimester and carries a fetal mortality of $5.6 \% .^{3}$ Analysis of fetal DNA is safer, and earlier diagnosis can be achieved if DNA is obtained from chorionic villi rather than amniotic fluid cells. ${ }^{4}$ However, $\beta$ thalassaemia is heterogenous and usually the abnormal DNA cannot be distinguished by hybridisation with total globin probe. When the molecular defects for $\beta$ thalassaemia in a particular population are defined oligonucleotide probes may be used to detect specific nucleotide mutations. ${ }^{5}$

For the present, linkage analysis is a feasible approach. We have shown that in the local Chinese population in Hong Kong there is pronounced linkage disequilibrium for BamH I polymorphism in normal subjects compared with those with $\beta$ thalassaemia, such that this single site may be used for prenatal diagnosis in $29 \%$ of the pregnancies at risk. For the remaining cases analysis of multiple restriction polymorphic sites around the $\beta$ gene cluster might show the appropriate site for prenatal diagnosis. ${ }^{2}$

We thank Dr T Maniatis for the $\beta$ globin probe; the Hong Kong University Research Fund and the Medical Faculty Research Fund for financial support; Dr Y M Cheung for help in collecting the samples; and Mr A Wong, Mr C S Kwan, and Mr C K Lai for skilful technical help.

\section{References}

1 Kan YW, Lee KY, Furbetta M, et al. Polymorphism of DNA sequence in the $\beta$-globin gene region. Application to prenatal diagnosis of $\beta^{\circ}$ thalassaemia in

2 Kazazian HH Jr, Phillips JA, Boehm CD, et al. Prenatal diagnosis of $\beta$-thalassaemias by amniocentesis: linkage analysis using multiple polymorphic restriction endonuclease sites. Blood 1980;56:926-30

3 Alter BP. Prenatal diagnosis of hemoglobinopathies: worldwide experience. Birth Defects 1982;18:263-74.

4 Old JM, Ward RHT, Petrou M, et al. First-trimester fetal diagnosis for haemoglobinopathies: three cases. Lancet 1982; ii:1413-6.

Pirastu M, Kan YW, Cao A, et al. Prenatal diagnosis of $\beta$-thalassaemia. Detection of a single nucleotide mutation in DNA. $N$ Engl $\mathcal{F}$ Med 1983;309:284-7.

(Accepted 26 fuly 1984)

○

\title{
Correlation between serum ionised calcium and serum albumin concentrations in two hospital populations
}

\author{
S J BUTLER, R B PAYNE, I R GUNN, J BURNS, C R PATERSON
}

\begin{abstract}
One quarter of 172 patients from two hospitals with no obvious disturbances of calcium homoeostasis and with total serum calcium concentrations that were normal after adjustment for albumin concentration had low serum ionised calcium concentrations. The low values were not due to changes in $\mathrm{pH}$ but were associated with hypoalbuminaemia. Significant positive regressions of ionised calcium on albumin concentration were observed in patients from both hospitals and also in 48 healthy laboratory staff. Because the regressions did not differ between patients and healthy subjects the low ionised calcium values associated with hypoalbuminaemia are unlikely to have been of pathological importance.

These findings indicate that interpreting serum ionised calcium concentrations in patients with a reduced serum albumin concentration on the basis of a reference range determined in subjects with a normal serum albumin concentration may be clinically misleading.
\end{abstract}

\footnotetext{
Department of Chemical Pathology, St James's University Hospital, Leeds LS9 7TF

S J BUTLER, PHD, MSC, biochemist

R B PAYNE, MD, FRCPATH, consultant chemical pathologist

Department of Biochemical Medicine, Ninewells Hospital, Dundee DD1 9SY

I R GUNN, MB, registrar

J BURNS, MSC, FIMLS, medical laboratory scientific officer

C R PATERSON, DM, FRCPATH, senior lecturer

Correspondence to: Dr R B Payne.
}

\section{Introduction}

Direct measurement of the ionised fraction of calcium in serum is generally accepted as the best way of detecting disturbances of calcium homoeostasis in patients with abnormal serum proteins. In vitro experiments, however, have raised the possibility that protein concentration itself can interfere with the measurement of ionised calcium, ${ }^{12}$ although this interpretation of the data has been disputed. ${ }^{3}$ We report here independent studies from St James's University Hospital, Leeds, and Ninewells Hospital, Dundee, investigating the relation between ionised calcium and albumin concentrations in hospital patients and laboratory staff.

\section{Subjects and methods}

Patients and normal controls-Seventy eight inpatients and 33 outpatients were studied in Leeds, and 61 inpatients in Dundee. They were adults of both sexes with no obvious clinical disturbance of calcium homoeostasis or acid base balance. We excluded patients in intensive care units, those with the nephrotic syndrome, those receiving haemodialysis, and those with serum total calcium concentrations adjusted for albumin concentration that fell outside the normal range $(2 \cdot 20-2 \cdot 60 \mathrm{mmol} / 1(8 \cdot 8-10 \cdot 4 \mathrm{mg} / 100 \mathrm{ml}))$. The adjustment for albumin concentration used in Leeds was total calcium ( $\mathrm{mmol} / \mathrm{l})+0.025$ $(40-$ albumin $(\mathrm{g} / \mathrm{l})),{ }^{4}$ and that used in Dundee was total calcium $(\mathrm{mmol} / \mathrm{l})+0.023(40$ - albumin $(\mathrm{g} / \mathrm{l}))$. Data were also obtained from healthy laboratory staff volunteers (48 in Leeds and 34 in Dundee).

Methods-In both hospitals serum albumin concentration was measured by a dye binding technique using bromocresol green and Technicon continuous flow automated equipment. In Leeds serum ionised calcium concentration was measured with a Nova 2 analyser and $\mathrm{pH}$ with an IL 313 blood gas analyser within two hours after collection of blood into a Vacutainer tube. In Dundee plasma containing $15 \mathrm{IU}$ lithium heparin $/ \mathrm{ml}$ was analysed for ionised calcium and 